DOI : $10.24198 / \mathrm{jkp}$

\title{
Relationship of Family Support Towards Self-Management and Quality of Life of Patients with Type 2 Diabetes Mellitus
}

\author{
Ahmad Yamin, Citra Windani Mambang Sari \\ Faculty of Nursing Universitas Padjadjaran \\ Email:citra_ners@yahoo.com
}

Submitted: 19-1-2018 Accepted: 10-8-2018 Published: 11-8-2018

\begin{abstract}
DM disease will be suffered for life, so the patient is expected to establish self-management behavior in managing the disease. Self-management behavior in patient tends to decline with increasing complications perceived by patients. The presence of social support one of important factors to improve adherence of self-management Diabetes patients. The purpose of this study was to assess the relationship of social support towards self-management and the quality of life in DM patients in Bandung. This research used correlational approach with purposive technique sampling. Numbers of respondent were taken from the region of 10 Puskesmas with highest DM in Bandung on 92 patients who came to Puskesmas. The questionnaires used were Hensarling Diabetes Family Support Scale (HDFSS), Summary of Diabetes Self-management Activities Measure (SDSCA) and SF-36. The analysis used analysis using frequency distribution, and Spearman-rho. Most respondents (51.1\%) had social support below the group median. Most respondents $(50 \%)$ had a quality of life below the group median. Most respondents $(52.2 \%)$ had DM self-management behavior below the group median. Bivariate results showed no relationship between social support support and self-management and quality of life of respondents ( $p$ value $=0.801$ ). There is no significant relationship between social support and self-management and quality of life. Therefore, the studies are expected to be recommendations of this study was integrate nursing care to improve self-management and quality of life of DM patients.
\end{abstract}

Keywords: Diabetes mellitus, quality of life, self-management, social support. 
Ahmad Yamin: Relationship of Family Support Towards Self-Management and Quality of Live

\section{Introduction}

Along with technological advances in the world of health, there has been a shifting disease pattern in the world. One of them is the number of diseases caused by lifestyle is growing more compared with the infectious diseases or other diseases. One of the diseases caused by lifestyle is Diabetes Mellitus. Based on data of WHO in 2010, the amount of DM patients in the world was 8.4 million people and Indonesia was ranked at the fourth largest number of DM patients in the world (WHO, 2010). Epidemiologically, WHO estimated that by 2030 the prevalence of DM in Indonesia will be reaching 21.3 million people (Ministry of Health Republic of Indonesia, 2011). Based on data of the International Diabetic Federation (IDF) in 2011, Indonesia was ranked at the 9th largest number in the world. The Results of Basic Health Research (Riskesdas) in 2013 conveyed that the prevalence of DM patients tended to be higher in urban than in rural area. Based on data of Riskesdas (2013) West Java Province was ranked at the 12th in Indonesia with the prevalence of $2 \%$ (Riskesdas, 2013). In Bandung, in 2010 the prevalence of DM disease reached 2\% (Health Profile Public Health Agency of West Java Province, 2010). Every year the data of DM patients in Indonesia not only experiences an increase in its prevalence but also its morbidity. According to WHO (2014), Diabetes mellitus was the third disease that caused death and required palliative care. Diabetes mellitus $(\mathrm{DM})$ is a metabolic disease characterized by elevated levels of blood glucose (hyperglycemia) occurs over a long period, due to insulin secretion abnormalities, insulin work, or either (ADA, 2013). DM disease will be suffered for life by the patient, therefore the patient is expected to establish self-management behavior in managing the disease.

The ability of DM patients in implementing self-care is influenced by internal and external factors (Orem, 2001). Internal factors can be influenced by individuals such as knowledge, self-efficacy, spiritual, while external factors are influenced by environments such as social support (Sonsona, 2014). Intensive family support was able to improve self- management behavior of type $2 \mathrm{DM}$ patients hence increased the motivational factor of Latino women who suffered from DM to have exercise (Choi, 2009), decrease HbA1C (Barrera, Toobert, \& Strycker, 2014) that ultimately affected the control of blood sugar and improved the quality of life of patients with type 2 DM (Isworo \& Saryono, 2010; Yusra, 2011; Tamara, Bayhakki \& Nauli, 2014; Rahmawati, Setiawati, \& Solehati, 2015). Research King et al. (2010), revealed that better social support will result in better persistence of self-management. Complying with a series of self-management actions that will last a lifetime is basically a big challenge and not an easy thing to do, feelings of bored that causes DM patients no longer discipline self-management actions so that family support is needed to help the patient has the ability to remain maintaining selfmanagement measures at an effective level in managing DM (Luthfa, Lukman, \& Sari, 2016; Gao et al., 2013).

Support from the family can increase motivation and prevent stress in people with type 2 diabetes mellitus (Antari et al., 2011), improve adherence to diet (Fauzia, Sari, \& Artini, 2013) and can improve selfmanagement behavior persistence (Huang et al., 2014) that will ultimately affect blood sugar control and improve the quality of life of DM patients (Wahyuni \& Anna, 2014; Yusra, 2011). In contrast to research conducted by Hasanat (2015) and Yin Xu et al. (2008) which states that there is no relationship between family support with selfmanagement in patients with DM. Handayani research (2012) states that the support of awards and information has no effect because the patient feels his own knowledge so that reject the information provided by the family. Similarly, Rosland et al. (2008) found no association of family support with medication adherence, diet, physical activity, and foot care. The purpose of this study was to assess the relationship between family support towards self-management and the quality of life of DM patients in Bandung.

\section{Method}

This research design was a descriptive 
Ahmad Yamin: Relationship of Family Support Towards Self-Management and Quality of Live

correlational study with a population of Diabetes patients registered in the 10 highest health centers in the city of Bandung those were Pasundan, Babakan Sari, Ramdan, Sarijadi, Arcamanik, Pasir Kaliki, Garuda, Ibrahim Adjie, Babakan Surabaya, and Ujung Berung. Researcher was collect data from a list of diabetes patients in the Puskesmas. The technique used non probability sampling. The inclusion criteria of respondents were 1) age more than 15 years old. The number of 92 samples were type 2 Diabetes Mellitus who came to Puskesmas. Number of samples is taken using the Slovin formula with an error rate of $10 \%$.

This study used 4 questionnaires. First, the questionnaire of Demographics Data of patients and families which was made by the researchers. Demographic data consist of general characteristics and health characteristics. Second, family support variables using Hensarling Diabetes Family Support Scale (HDFSS). This questionnaires consists of 25 statements with the answer of choice always, often, rarely and never include about infomational support, award support, emotional support and instrumental support. Third, self-management using modification of instrument of Summary of Diabetes Selfmanagement Activities Measure (SDSCA) (Toobert, Hampson \& Glasgow, 2000) and DSMI . Self-management Diabetes mellitus questionnaires consist of 29 statements with answer choices always, often, rarely, never. The questionnaire covered 5 domains: exercise, diet, health care control, and blood sugar checks. Fourth, the quality of life using

Table 1 Respondents' Characteristics

\begin{tabular}{|c|c|c|}
\hline Variable & $\mathrm{N}$ & $\%$ \\
\hline Puskesmas (Public Health Center & & 5.4 \\
\hline Pasundan & 5 & 8.7 \\
\hline Babakan Sari & 8 & 14.1 \\
\hline M. Ramdan & 13 & 10.9 \\
\hline Sarijadi & 10 & 8.7 \\
\hline Arcamanik & 8 & 12 \\
\hline Pasirkaliki & 11 & 9.8 \\
\hline Garuda & 9 & 6.5 \\
\hline Ibrahim Adjie & 6 & 13 \\
\hline Babakan Surabaya & 12 & 10.9 \\
\hline Ujung Berung & 10 & \\
\hline
\end{tabular}

the quality of life for DM patient instrument from SF-36. SF-36 questionnaire consists of 11 statements with a choice of answers always, every so often, sometimes, once in a while, never which consist of health conditions, physical activity, social activities and pain. The three questionnaires have been tested for validity and reliability.

Data processing was done by descriptive and inferential. Descriptive data analysis was used to process the patients and family demographic data, family support, selfmanagement of DM patients, and the quality of life. The data were presented in the form of Median and Quartile. Inferential analysis was used to identify the relationship of family support towards self-management DM patients and the quality of life by using Spearman-rho analysis.

All the respondents in the study got explanation both verbally and in writing about this research. The respondents' willingness were considered by a written or verbal statement by them. Researchers had ensured that participation in the study was voluntary and they can take off participating at any time without negative consequences. The contact information of the researchers (telephone and address) was given to the research subject. All information was kept confidential. The results of the study were reported in groups and only for academic purposes. There was no hazard to participate in this research.

\section{Result}


Ahmad Yamin: Relationship of Family Support Towards Self-Management and Quality of Live

\begin{tabular}{|c|c|c|}
\hline Age & & 57.6 \\
\hline $40-50$ years old & 53 & 42.4 \\
\hline $60-69$ years old & 39 & 29.3 \\
\hline Gender & & 70.7 \\
\hline Male & 27 & \\
\hline Female & 65 & 3.3 \\
\hline Marital Status & & 75 \\
\hline Not yet married (single) & 3 & 21.7 \\
\hline Married & 69 & 84.8 \\
\hline Widow/Widower & 20 & 15.2 \\
\hline Ethnic & & 71.7 \\
\hline Sundanese & 78 & 10.9 \\
\hline Javanese & 14 & 4.3 \\
\hline Occupation & & 4.3 \\
\hline House wife & 60 & 4.3 \\
\hline Labor & 10 & 4.3 \\
\hline Civil Employees & 4 & \\
\hline Private employees & 4 & 1.1 \\
\hline Enterpriser & 3 & 39.1 \\
\hline Other & 3 & 30.4 \\
\hline Education & 28 & 5.4 \\
\hline Unschooling & 5 & \\
\hline Elementary school & 36 & \\
\hline Junior high school & 28 & \\
\hline Senior high school & & \\
\hline University & & \\
\hline
\end{tabular}

Table 2 Respondents' Clinical Characteristics

\begin{tabular}{|c|c|c|}
\hline Variable & $\mathrm{n}$ & $\%$ \\
\hline Duration of Diabetes & & 59.8 \\
\hline Less than 3 years & 55 & 40.2 \\
\hline $\begin{array}{c}\text { More than 3 years } \\
\begin{array}{c}\text { Complaints after taking the } \\
\text { medicine }\end{array}\end{array}$ & 37 & \\
\hline Yes & 22 & 76.1 \\
\hline No & 70 & \\
\hline Smoking & & 71.7 \\
\hline Never & 66 & 10.9 \\
\hline Ever & 10 & 17.4 \\
\hline Still & 18 & 33.6 \\
\hline Activity & 31 & 66.3 \\
\hline Working & 61 & \\
\hline Doing household chores & & \\
\hline
\end{tabular}


Ahmad Yamin: Relationship of Family Support Towards Self-Management and Quality of Live

\begin{tabular}{|c|c|c|}
\hline Exercise/Sport & & 58.3 \\
\hline Never & 26 & 64.1 \\
\hline Walking & 59 & 1.1 \\
\hline Running & 1 & 6.5 \\
\hline Gymnastic & 6 & 64 \\
\hline Diet & 59 & 35.9 \\
\hline Regular & 33 & 14.1 \\
\hline Irregular & & 87.8 \\
\hline Control to hospital & 13 & \\
\hline Regular & 79 & 58.7 \\
\hline Irregular & & 41.3 \\
\hline Co-morbid & 54 & \\
\hline Yes & 38 & 12 \\
\hline No & & 60.9 \\
\hline BMI & 11 & 21.7 \\
\hline Thin & 56 & 5.4 \\
\hline Normal & 20 & \\
\hline Overweight & 5 & \\
\hline Obese & & \\
\hline
\end{tabular}

Tabel 3 Mean, Standard Deviation and Self-management Level of DM and the Quality of Life of DM Patients

\begin{tabular}{|c|c|c|c|c|c|c|c|}
\hline Variable & \multirow{2}{*}{$\begin{array}{c}\text { Min-Max } \\
\text { Score }\end{array}$} & \multirow{2}{*}{ Mean } & \multirow{2}{*}{ SD } & \multicolumn{2}{|c|}{ Below Median } & \multicolumn{2}{c|}{ Above Median } \\
\cline { 5 - 8 } & & & & $\mathrm{f}$ & $\%$ & $\mathrm{f}$ & $\%$ \\
\hline Self-management & $31-108$ & 80.29 & 12.11 & 48 & 52.2 & 44 & 47.8 \\
\hline Quality of Life & $72-111$ & 91.23 & 7.31 & 46 & 50 & 46 & 50 \\
\hline Family Support & $88-263$ & 173.97 & 48.63 & 47 & 51.1 & 45 & 48.9 \\
\hline
\end{tabular}

Table 4 The Results of Bivariate Analysis

\begin{tabular}{|c|c|c|c|c|}
\hline \multirow{2}{*}{ Subvariabel } & \multicolumn{2}{|c|}{ Self-management } & \multicolumn{2}{c|}{ Quality of Life } \\
\cline { 2 - 5 } & $\begin{array}{c}\text { Correlation } \\
\text { coefficient }\end{array}$ & p-value & $\begin{array}{c}\text { Correlation } \\
\text { coefficient }\end{array}$ & p-value \\
\hline Social Support & 0.27 & 0.801 & 0.27 & 0.801 \\
\hline
\end{tabular}

From the table above, it can be seen that the sample was dominated at the age of $40-59$ years $(57.6 \%)$ with female gender $(70.7 \%)$, Sundanese $(84.8 \%)$, married status $(75 \%)$, occupation as the housewives $(71.7 \%)$, elementary school education (39.1\%).

From the table above can be obtained that the clinical data of respondents who had suffered DM less than 36 months (55\%), with no complaints after taking medicine $(76.1 \%)$, did not smoke $(71.7 \%)$, did the household chores $(66.3 \%)$, had a walk for sport $(64.1 \%)$, had regular diet $(64.1 \%)$, controlled to doctors/hospital irregularly (87.8\%), had no co-morbid disease than DM (58.7\%) and got a Normal BMI (60.9\%).

From the table above, most respondents $(51.1 \%)$ had social support below the group median. Most respondents $(50 \%)$ had a quality of life below the group median. Most respondents $(52.2 \%)$ had DM selfmanagement behavior below the group median. Bivariate results showed no relationship between social support and selfmanagement and quality of life of respondents $(\mathrm{p}$ value $=0.801)$. 
Ahmad Yamin: Relationship of Family Support Towards Self-Management and Quality of Live

\section{Discussion}

\section{The Relationship of Family Support with Self-management of DM Patients}

Family support is the help given by other family members so it will provide physical and psychological comfort for people who faced the stressful situations (Taylor, 2006). The process of family support will occur during the lifetime, with the nature and type of social supports varying in each stage of the family life cycle. However, in all stages of the life cycle, family social support allows the family to fully function and can improve adaptation to family health (Friedman, 2010). Several studies have shown a relationship of family support to self-management of DM patients. In this study did not prove it. This is similar to the Hasanat study (2015) and Hidayati (2017), that family support has no contribution with self-management DM. According to Shumaker \& Hill (in Hasanat, 2015), a too deep family support can cause stress if the support given in the form of control or rule, in addition, will benefit the emergence of healthy behavior, but it also can provoke stress to the patients so that affected on the self-management. According to $\mathrm{Xu}$ et al (2008), that family support has no relationship with self-management. However, family support will be indirectly influenced by the patient's own convictions in order to perform self-management well (Xu et al, 2008). In another study of 164 participants with DM, Rosland et al. (2008) found no relationship of family support with medication adherence, diet, physical activity, and foot care due to factors such as family characteristics and family culture itself thus influenced self-management in AfricanAmericans. Similarly, Gallant's study (2003) found no strong relationship between support with pharmacotherapy adherence and monitoring glucose levels due to lack of family knowledge and understanding that sometimes limiting them to help with the emotional support that would be a barrier to self-management activities of people with chronic disease.

From the analysis of family support to self-management, there is no relationship between the two sub variables due to internal factors such as gender. In this study more are women who do not work. From the results of family support analysis of self-management, there is no relationship between the two sub variables due to internal factors such as sex and employment background. In this study more are women who do not work. In addition it is of the duration of DM felt by the patient. Most of the respondents are those who have DM duration less than 3 years.

In accordance with Huang, Zhao, Li, and Jiang, (2014) that family support can increase the persistence of self-management behavior. The supports given could be material and spiritual supports that will reduce psychological stress, relieve tension, improve social adaptability and patients will be more determined to fight the disease. In patients who have been diagnosed with DM, the participation of other family members in guiding medication, diet, physical exercise and positive spare time for family's health are the active roles for the success of DM selfmanagement.

Along with the time, the family is the largest resource for DM patients' selfmanagement at home. The family in its function as the primary caregiver provides continuous care that is needed deliberately over time (Luthfa, Lukman, \& Sari, 2016). Regardless of the type of chronic illness experienced, the family is challenged to try helping family members who diagnosed with DM in order to stay healthy, to prevent additional complications, to incorporate changes in physical and mental status in the role and function of the family, and to manage any complications or disabilities (Kaakinen, Hanson, \& Denham, 2010).

\section{The Relationship of Family Support with Quality of Life of DM patients}

The results of this study, there is no relationship with between family support and quality of life on the respondents. It meant, different from the previous research. The greatest relation value was shown by Antari et al.'s study (2011) which stated there was a significant relationship between family support and quality of life of Type 2 DM patients ( $p$-value $=0.000)$ with an influence contribution of $95.5 \%$. While the results of Yusra's research (2011) stated that there was a relationship between family support and 
Ahmad Yamin: Relationship of Family Support Towards Self-Management and Quality of Live

quality of life Type $2 \mathrm{DM}$ patients ( $\mathrm{p}$-value $=0.001, \mathrm{r}=0.703)$. According to Antari, Rasdini, and Triyani (2011), the social support was very helpful for people with type 2 diabetes to be able to increase confidence in their ability in doing self-management. From these results, family support has a negative impact on patients' quality of life. This could be because the patients are already independent and no longer need the family support. In addition, the assumptions of family support researchers are below the median due to many factors. Age, gender, education and health characteristics of respondents such as old DM, comorbid disease owned.

\section{Conclusion}

There is no significant relationship between social support and self-management and quality of life. the results of this study can be used as a basis for other research and integrated nursing care to improve selfmanagement and quality of life of DM patients.

\section{References}

American Diabetes Association. (2013). Physical activity is important. Available at: $\mathrm{http}: / /$ care.diabetesjournals.org (Accessed on 28 June 2013).

Antari, G.A.A., Rasdini, I.D.A., \& Triyani, G.A.P. (2011). Besar pengaruh dukungan sosial terhadap kualitas hidup pada pedertia diabetes melitus tipe 2 di Poliklinik Interna RSUP Sanglah. Available at: http://www. unund.ac.id pada tanggal 23 Oktober 2016.

Barrera, M., Toobert D.J., \& Strycker, L.A. (2014). Relative contributions of naturalistic and constructed support: Two studies of women diabetes with type 2 diabetes. Journal of Behavioral Medicine, 37, 56-69.

Choi, S.E. (2009). Diet specify family support and glucose control among Korean Immigrants with type 2 diabetes melitus. The Diabetes Educator 35(6), 978-985.
Dinkes Jabar. (2012) Profil kesehatan Provinsi Jawa Barat tahun 2012. Bandung. Dinas Kesehatan Kota Bandung.

Fauzia, Y., Sari, E., \& Artini, B. (2013). Gambaran faktor-faktor yang mempengaruhi kepatuhan diet penderita diabetes mellitus di Wilayah Puskesmas Pakis Surabaya.

Friedman, M.M., Bowden, V.R., \& Jones, E.G. (2010). Buku ajar keperawatan keluarga: Riset, teori dan praktik, alih bahasa, Akhir Yani S. Hamid dkk; Ed. 5. Jakarta: EGC.

Gao, J., Wang, J., Zheng, P., Haardorfer, R., C Kegler, M., Zhu, Y., .., et al. (2013). Effects of self-care, self-efficacy, social support on glycemic control in adults with type 2 diabetes. 10.1186/1471-2296-14-66.

Handayani, S.D. (2012). Hubungan dukungan keluarga dengan kekambuhan pasien gastritis di Puskesmas Jatinangor. Skripsi. Universitas Padjajaran, Bandung.

Hasanat, N.U. (2015). Analisis kuantitatif faktor-faktor psikososial pada paien diabetes melitus tipe 2. Ringkasan Disertasi. Universitas Gajah Mada, Yogyakarta.

Hensarling. (2009). Development and psychometric testing of Hensarling's diabetes family support scale, a dissertation. Degree of Doctor of Philosophi in the Graduate School of Texa's Women"s University.

Hidayati, L. (2017). Hubungan dukungan keluarga dengan self-management pada penderita diabetes mellitus tipe 2. Naskah Publikasi pada http://repository.umy.ac.id/ bitstream/handle/123456789/15295/12.\%20 N A S K A H \% 20 P U B L I K A S I . pdf?sequence $=12$ \&isAllowed $=y$. Universitas Muhammadiyah Yogyakarta,

Internatioal Diabetes Federation (2015). 2015, IDF Diabetes Atlas (7th Ed.). Retrieved from http://www.oedg.org.

Kaakinen, J.R., Hanon, S.H., \& Denham, S.A. (2010). Family health care nursing, theory practice and researche (4th Ed., Chapter 1). Davis Company, Philadelphia. 
Ahmad Yamin: Relationship of Family Support Towards Self-Management and Quality of Live

Kemenkes. (2013). Profil kesehatan Indonesia tahun 2013. Jakarta: Kemenkes RI.

King, D.K., Glasgow, R.E., Toobert, D.J., Strycker, L.A., Estabrooks, P.A., ..., et al. (2010). Self-efficacy, problem solving, and social-environmental support are associated with diabetes self-management behaviors. Diabetes Care, 33, 751-3.

Luthfa, I., Lukman, M., \& Sari, S.P. (2016). Family support pada penderita diabetes mellitus tipe 2 di Puskesmas Bangetayu Semarang. Tesis. Universitas Padjajaran, Bandung.

PERKENI. (2011). Konsensus pengelolaan dan pencegahan diabetes melitus tipe 2 di indonesia 2011.

Riskesdas. (2013). Penyajian pokok-pokok hasil riset kesehatan dasar 2013. Badan Penelitian dan Pengembangan Kementerian Kesehatan Republik Indonesia.

Rosland, A.M., Kieffer, E., Israel, B., Cofield, M., Palmisano, G., Sinco, B., \& Heisler, M. (2008). When is social support important? The association of family support and professional support with specific diabetes self-management behaviors. Journal of General Internal Medicine, 23(12), 19921999. doi:10.1007/s11606008-0814-7.

Sonsona, J.B. (2014). Factors influencing diabetes self-management of Filipino Americans with type 2 diabetes mellitus: A Holistic Approach.

Taylor, S.E. (2006). Health psychology (6th Ed.). Singapore: MC. Grow Hill Book Company.

Wahyuni, Y., \& Anna, A. (2014). Kualitas hidup berdasarkan karekteristik pasien diabetes melitus tipe 2. Skripsi. Universitas Padjajaran, Bandung.

World Health Organization. (n.d.) WHO, (2014). 10 facts about diabetes melitus. www.google.com.
Xu, Y., Toobert, D., Savage, C., Pan, W., \& Whitmer, K. (2008). Factors influencing diabetes self-management in Chinese people with type 2 diabetes. Research in Nursing and Health, 31(6), 613-625. doi:10.1002/ nur.20293.

Yusra, A. (2011). Hubungan antara dukungan keluarga dengan kualitas hidup pasien diabetes mellitus tipe 2 di Poliklinik Penyakit Dalam Rumah Sakit Umum Pusat Fatmawati Jakarta. Tesis. Universitas Indonesia, Jakarta. 